\title{
Model Pengembangan Kualitas Hubungan Students College Exchange Berbasis Public Relations Evaluation
}

\author{
Imam Nuraryo ${ }^{1}$ \\ ${ }^{1}$ Institut Bisnis dan Informatika Kwik Kian Gie
}

\begin{abstract}
ABSTRAK
Tujuan penelitian ini untuk menggali kajian-kajian mengenai pengukuran dan pengembangan hubungan yang dilakukan oleh perguruan tinggi sebagai produsen layanan pendidikan dan mahasiswa sebagai penerima jasa pendidikan (pelanggan) dengan mengadopsi model pengembangan hubungan Relationship Quality-based Students Loyalty (RSQL), Guidelines for Measuring Relationship in Public Relations sebagai pengembangan dari konsep pemasaran relasional dan model pertukaran sosial dari Thibault dan Kelly. Penelitian ini dilakukan untuk menguji adanya hipotesis bahwa mahasiswa yang tidak melanjutkan kuliahnya dikarenakan layanan pada perguran tinggi yang tidak memuaskan. Di samping itu, penelitian ini menyajikan model-model lain dalam pengembangan hubungan berikut disertai contoh operasionalisasi variabel yang digunakan untuk mengukur hubungan tersebut. Teknik pengambilan sampel dalam penelitian ini adalah menggunakan sampel gugus bertahap. Populasi sampel penelitian ini adalah sebanyak 362 mahasiswa yang saat ini menempuh studi di tiga perguruan tinggi bisnis di Jakarta. Penelitian ini dilakukan selama dua pekan selama bulan September sampai dengan November 2017. Hasil penelitian menunjukkan bahwa terdapat hubungan antara kualitas layanan terhadap loyalitas mahasiswa melalui kualitas hubungan. Selain itu, terdapat pula hubungan citra perguruan tinggi terhadap loyalitas mahasiswa yang dimediasi oleh kualitas hubungan. Kesimpulannya adalah bahwa kualitas hubungan memberikan pengaruh yang cukup signifikan terhadap peningkatan loyalitas mahasiswa sebagai variabel yang memediasikan pengaruh kualitas layanan dan citra perguruan tinggi. Rekomendasi bagi perguruan tinggi bersangkutan adalah untuk memperhatikan dimensi-dimensi kualitas hubungan seperti kepercayaan, komitmen, nilai-nilai dan kepuasan mahasiswa.
\end{abstract}

Kata-kata Kunci: Evaluasi; humas; mahasiswa; pendidikan; perguruan tinggi

\section{Service Quality Developing Model Students College Exchange Based On Public Relations Evaluation}

\begin{abstract}
The purpose of this research is to explore studies on the measurement and development of relationships conducted by universities as a provider of educational services and students as recipients of education services (customers) by adopting a relationship development model of Relationship Quality-Based Students Loyalty (RSQL) Guidelines for Measuring Relationship in Public Relationsas the development of relational marketing concepts and social exchange models from Thibault and Kelly. In addition, this paper presents other models in the development of the following relationships with an example of the operationalization of variables used to measure those relationships. The sampling technique in this research is to use the gradual group sample. The sample population of this study is 362 students currently studying at three business colleges in Jakarta. This study was conducted for two weeks during September to November 2017. The results showed that there is a relationship between service quality to student loyalty through relationship quality. In addition, there is also a college image relationship to student loyalty mediated by the quality of relationships. The conclusion is that the quality of the relationship gives a significant influence on the improvement of student loyalty as a variable that mediates the influence of service quality and college image. The recommendation for the college concerned is to pay attention to the quality dimensions of relationships such as trust,commitment,values and student satisfaction.
\end{abstract}

Keywords: Education; evaluation; public relations; students; universities

Korespondensi: Imam Nuraryo, Institut Bisnis dan Informatika Kwik Kian Gie, Jln. Yos Sudarso Kav. 87 Sunter, Jakarta 14350.Email: imam@kwikkiangie.ac.id 


\section{PENDAHULUAN}

Perguruan tinggi swasta (PTS) memiliki tantangan yang cukup besar saat ini. Banyak PTS yang gulung tikar ataupun menutup program studinya karena kalah bersaing. Menurut data APTISI pusat, sebanyak 30 persen atau 800an perguruan tinggi swasta (PTS) di Indonesia gulung tikar (Tobari, 2015). Bangkrutnya PTSPTS tersebut terutama disebabkan tidak ada atau kurangnya minat calon mahasiswa yang mau mendaftar pada PTS tersebut. Jika PTS terlalu mengandalkan dana mahasiswa untuk membiayai operasionalnya, maka kemungkinan kecil PTN tersebut dapat bertahan. Namun hal tersebut memang harus didukung dengan modal awal yang sangat besar. Tidaklah heran sekarang ini banyak perguruan tinggi baru yang memang dibuat oleh perusahaan-perusahaan yang cukup besar seperti Lippo Group, Podomoro, Telkom atau Pertamina.

Kenyataannya sampai saat ini, bagi PTSPTS yang tidak didukung oleh perusahaanperusahaan besar semacam itu, sumber dana PTS sebagian besar memang tetap berasal dari mahasiswa. Jumlah PTS yang mengandalkan dana dari mahasiswa jelas lebih banyak dibanding PTS-PTS yang didanai oleh perusahaan-perusahaan besar. Walaupun demikian, masih banyak PTS yang berjuang untuk tetap membuka program studi meskipun jumlah mahasiswanya tidak memadai.

PTS selain selalu berusaha untuk mendapatkan mahasiswa sebanyak-banyaknya, juga PTS perlu memperhatikan agar mahasiswa yang sudah terjaring, tidak serta merta putus di tengah jalan. Apabila hal tersebut terjadi, maka hal tersebut jelas akan memengaruhi keuangan dari PTS tersebut. Hal tersebut sejalan dengan apa yang dikemukakan oleh Kara \& Deshiled, yang menyatakan bahwa keberhasilan perguruan tinggi dalam mempertahankan jumlah mahasiswa dari mereka terdaftar sampai dengan lulus wisuda, justru dapat meningkatkan pendapatan perguruan tinggi tersebut (Kara, 2004).

Hal ini disebabkan karena mempertahankan mahasiswa sebagai pelanggan yang sudah ada, tentunya memerlukan biaya yang lebih rendah daripada harus mencari mahasiswa baru. Mempertahankan mahasiswa yang sudah ada juga banyak dipengaruhi oleh dukungan kualitas layanan kepada mahasiswa. Untuk itu, maka perguruan tinggi swasta perlu memperhatikan layanan yang prima terhadap para mahasiswanya agar jangan sampai mereka terhenti studinya selama di perguruan tinggi (Alma, 2005).

Salah satu faktor yang menyebabkan mahasiswa tidak melanjutkan studi adalah ketidakpuasan mereka terhadap layanan perguruan tinggi. Ketidakpuasan yang 
dimaksud adalah rasa tidak puas terhadap lingkungan akademik, peraturan-peraturan, dan lingkungan sosial. Ketidakpuasan mahasiswa ini juga dapat berawal dari perilaku organisasi yang tidak ramah dalam melayani atau sulit untuk menerima kritik. Tidak jarang mahasiswa cenderung memutuskan untuk tidak melanjutkan perkuliahannya karena alasan tersebut (Ramist, 1981).

Sesungguhnya, ada faktor lain yang sering dilupakan dalam peningkatan loyalitas mahasiswa. Faktor tersebut adalah kualitas hubungan. Peningkatan loyalitas pelanggan tidak cukup hanya dengan meningkatkan kepuasan mahasiswa. Loyalitas mahasiswa sebagai pelanggan dapat dipengaruhi pula dengan meningkatkan kualitas hubungan antara perguruan tinggi sebagai penyedia jasa dan mahasiswa sebagai konsumer (Henning \& Langer, 2001).

Kualitas hubungan ini meliputi tidak hanya berbicara mengenai kepuasan pelanggan, namun juga meliputi kepercayaan yang diberikan pelanggan pada penyedia jasa, komitmen pelanggan, dan persepsi pada nilai. Aspekaspek yang terdapat di dalam kualitas hubungan ini merupakan upaya dalam meningkatkan hubungan yang lebih baik dengan pelanggan melalui perbaikan layanan pada pelanggan yang sudah ada, atau dikenal dengan istilah Relationship Marketing (Alma, 2005).
Dalam ruang lingkup kajian Manajemen atau Public Relations, konsep Relationship Marketing dikenal dengan istilah Customer Relationship Management (CRM). Konsep ini merupakan hubungan kerja sama antara pihak penyedia jasa dengan pelanggan, sehingga kedua pihak saling menguntungkan. Dalam hal ini, lembaga tidak menekankan pada terjualnya produk, tetapi lebih fokus pada interaksi dan komunikasi secara menyeluruh dengan elemenelemen kegiatan bisnis yang dikelola oleh lembaga (Kriyantono, 2014).

\section{METODE PENELITIAN}

Metode yang digunakan dalam penelitian ini adalah survei eksplanatori. Analisis data hasil pengumpulan data menggunakan Model persamaan struktural. Model ini digunakan untuk menunjukkan pengaruh kualitas layanan dan citra perguruan tinggi melalui kualitas hubungan terhadap variabel loyalitas mahasiswa di tiga Institut Bisnis di Jakarta. Ukuran sampel pada penelitian ini sebanyak 362 mahasiswa dari program studi Akuntansi dan Manajemen, yang terdaftar di tiga perguruan tinggi bisnis yang berjenis Institut yang mendapat predikat terbaik se - Jakarta tahun 2016.

Kualitas hubungan seringkali menjadi variabel anteseden atau variabel antara untuk mengukur seberapa tinggi loyalitas pelanggan. Pada konteks pendidikan tinggi, kualitas 
hubungan dapat menjadi variabel pendahulu untuk mengukur loyalitas mahasiswa pada perguruan tinggi yang dapat memainkan peran penting dalam keberlangsungan hidup sebuah perguruan tinggi (Taecharungroj, 2013).

Alasan mengapa loyalitas mahasiswa yang diteliti adalah karena khususnya bagi perguruan tinggi swasta, loyalitas mahasiswa merupakan faktor penting untuk mempertahankan keberlangsungan hidup organisasi PT itu sendiri. Loyalitas mahasiswa dianalogikan sebagaimana loyalitas pelanggan di dalam perusahaan-perusahan yang bergerak dalam bidang komersil laba.

Keterbukaan ekonomi yang mendorong pemerintah untuk membuka peluang masuknya perguruan tinggi asing, semakin memperketat persaingan antar perguruan tinggi di peta industri pendidikan tinggi nasional. Oleh karena itu, PTS perlu memperhatikan kualitasnya agar mampu bersaing dengan PTS-PTS lainnya. Dalam hal ini, PTS harus memberikan jaminan kepuasan dan layanan pada para mahasiswanya.

\section{HASIL DAN PEMBAHASAN}

Teori pertukaran sosial menjadi sumber dan fondasi sekaligus memberikan kontribusi dalam menjelaskan teori hubungan organisasi - pemangku kepentingan (Organizational Stakeholder Theory) dan pemangku kepentingan serta teori hubungan pemasaran atau pemasaran relasional (Relationship Marketing). Teori ini juga dapat digolongkan teori Public Relations yakni teori yang dapat menjelaskan fenomena Public Relations, walaupun tidak termasuk teori kekhasan Public Relations (Kriyantono, 2014).

Namun demikian, teori ini merupakan landasan pembentukan teori Relationship Management, yakni teori yang membahas aktivitas komunikasi yang menghubungkan organisasi dan publiknya. Metode dalam teori Relationship Management yang paling banyak digunakan yakni metode untuk mengukur kualitas hubungan organisasi dan publiknya, yang dirumuskan oleh Hon dan Grunig. Metode ini terdiri dari empat dimensi yakni kepercayaan, komitmen, kepuasan dan kontrol kebersamaan atau kendali mutualitas (Kriyantono, 2014).

Teori ini pada awalnya dibangun oleh Homans dari kajian Sosiologi dan Thibaut dan Kelley dari perspektif Psikologi Sosial. Premis dasar yang dibangun oleh teori ini adalah bahwa perilaku sosial ditunjukkan dengan adanya pertukaran aktivitas, baik yang nampak atau tidak nampak, yang dilakukan oleh paling sedikit terdiri dari dua orang.

The early development of a theory of social exchange is largely attributed to the work of Homans (1961) in Sociology and Thibaut and Kelley (1959) in psychology. The Basic premise of which social exchange theory has been developed is that social behavior presents an exchange of activity, tangible or intangible, and more or less rewarding or costly, between at least two persons. 
Menurut Ardianto, teori pertukaran sosial merupakan salah satu teori psikologi sosial yang dapat digunakan untuk menjelaskan fenomena berupa aktivitas-aktivitas Public Relations, dimana Public Relations juga merupakan salah satu bagian/bidang dari ilmu komunikasi (Ardianto, 2014). Teori ini menggambarkan sifat-sifat yang muncul dari interaksi sosial. Semula teori ini digunakan untuk menggambarkan bagaimana membentuk, mengembangkan dan melemahkan hubungan sosial pada ranah hubungan antar pribadi. Selanjutnya, teori ini juga digunakan untuk melihat karakteristik hubungan antara individu pemangku kepentingan dan organisasi.

Pertukaran sosial berbeda dengan pertukaran ekonomi. Pertukaran sosial secara relatif informal melibatkan kewajiban yang tidak dilihat secara spesifik, namun dapat dilihat dalam pertukaran lebih lanjut. Menurut Syam seperti halnya teori pembelajaran sosial dari Bandura, teori pertukaran sosial pun melihat antara perilaku dengan lingkungan terhadap hubungan yang saling memengaruhi (resiprokal) (Syam, 2011).

Thibaut dan Kelley pada mulanya menitikberatkan pada penggunaan teori ini dalam konsep-konsep psikologi yang terjadi pada hubungan atau komunikasi antar pribadi dan kelompok kecil. Asumsi yang mendasarinya adalah bahwa setiap individu secara sukarela memasuki dan tinggal dalam hubungan sosial hanya selama hubungan tersebut cukup memuaskan ditinjau dari segi ganjaran dan biaya. Ganjaran, biaya, laba dan tingkat perbandingan menjadi konsep pokok teori ini (Rakhmat, 2007).

Ganjaran adalah setiap akibat positif yang diperoleh seseorang dari suatu hubungan. Ganjaran dapat berupa uang, penerimaan sosial, atau dukungan serta layanan. Biaya adalah akibat yang dinilai negatif yang terjadi dalam suatu hubungan. Biaya dapat berupa waktu, usaha, hal yang tidak menyenangkan, konflik, kecemasan, dan keruntuhan harga diri. Laba adalah ganjaran dikurangi biaya. Sedangkan tingkat perbandingan adalah ukuran standard yang dipakai sebagai kriteria dalam menilai hubungan individu pada waktu sekarang (Syam, 2011)

Terdapat ringkasan singkat teori ini ke dalam tiga proposisi. Proposisi pertama adalah proposisi sukses, makin sering suatu tindakan tertentu memeroleh imbalan, maka cenderung orang tersebut menampilkan tindakan tertentu tersebut. Proposisi kedua yakni proposisi stimulus, yang menyatakan bahwa makin tinggi nilai hasil suatu perbuatan bagi seseorang, kemungkinan besar perbuatan tersebut akan diulanginya.

Proposisi ketiga yakni DeprivationSatiation Proposition, yakni seseorang dalam 
hubungan pertukaran dengan orang lain akan mengharapkan imbalan yang diterima oleh setiap pihak sebanding dengan investasinya. Dengan kata lain, makin tinggi investasi, makin tinggi keuntungan. Pada prinsipnya, imbalan yang diterima oleh orang lain akan menentukan sikap selanjutnya, yakni individu tersebut akan melanjutkan hubungan tersebut atau tidak.

Thibaut dan Kelley juga menyatakan dua konseptualisasi. Pertama adalah fokus pada sifat dasar manusia dan keduanya adalah sifat dasar dari hubungan. Ada tiga asumsi pada konsep yang pertama yaitu; (a) manusia mencari penghargaan dan menghindari hukuman, (b) manusia adalah makhluk yang rasional dan (c) standard yang digunakan oleh manusia untuk mengevaluasi pengorbanan dan penghargaan bervariasi seiring dengan berjalannya waktu. Konsep yang kedua terdapat dua asumsi yakni, hubungan memiliki sifat ketergantungan dan kehidupan berhubungan adalah sebuah proses (West \& Turner, 2009). Namun demikian, Blau menyatakan teori ini dari sudut pandang ekonomi dan utilitarian. Berbeda halnya dengan Homan yang memfokuskan prinsip penguatan (Reinforcement) berdasarkan pengalamanpengalaman masa lalu, Blau menekankan pada ganjaran apa yang dapat diberikan berdasarkan interaksi sosial di masa depan (Blau, 1964).

Teori pertukaran sosial mampu menjelaskan proses kepuasan yang diperoleh oleh seseorang jika mereka mendapatkan "pengembalian” yang wajar, atas apa yang telah mereka korbankan (yakni biaya atau harga yang telah mereka bayarkan). Penerapan teori pertukaran sosial pada awalnya adalah mengkaji hubungan dan komunikasi antar pribadi. Namun demikian, teori ini juga menjadi bahan landasan dalam beberapa situasi-situasi yang lain, yang menggunakan ide atau gagasan yang sama yang berkaitan dengan pertukaran-pertukaran berbagai macam sumber daya (Blau, 1964).

Amal menyatakan bahwa "Setiap pertukaran sosial terjadi dalam konteks jaringan pertukaran sosial yang lebih besar. Pertukaran tidak saja terjadi antar dan melibatkan dua orang saja, melainkan bisa terjadi antar dan melibatkan berbagai pihak, instansi, organisasi”. Dengan kata lain, teori pertukaran sosial tidak sekedar hanya dapat diaplikasikan ke dalam konteks komunikasi antar pribadi, namun dapat diaplikasikan ke hubungan yang lebih kompleks dan berbagai bidang (Alma, 2005).

Tujuan utama Teori Pertukaran Sosial ialah untuk memprediksi dan menjelaskan perilaku. Menurut Teori Pertukaran Sosial, kita dapat memprediksi dan menjelaskan perilaku melalui sebuah pemahaman tentang faktor-faktor yang individu-individu memperhitungkan mengenai segala sesuatu (imbalan-imbalan dan biayabiaya) dalam membuat keputusan-keputusan tentang tindakan-tindakan mereka. Umat 
manusia dilihat sebagai makhluk-makhluk rasional yang, pada tingkat tertentu, terlibat dalam sebuah analisis untung rugi.

Teori pertukaran sosial pula yang menjadi salah satu teori yang meletakkan fondasi bagi pengembangan konsep relasi pemasaran (Relationship Marketing) selain dari teori kontrak relasional dan teori ketergantungan sumber daya. Adanya dimensi kepercayaan, komitmen dan persepsi nilai yang terdapat dalam proses timbal balik antara produsen dan konsumen, adalah bersumber dari teori pertukaran sosial. Dimensi-dimensi tersebutlah yang memberi pemahaman mengenai Relationship Marketing.

RelationshipMarketing Theory menyatakan bahwa pada saat perusahaan menyampaikan nilai kepada pelanggan, maka perusahaan akan memperkuat hubungannya dengan pelanggan. Hubungan perusahaan dengan pelanggan akan meningkat dengan harapan pelanggan akan tetap memiliki kesetiaan pada perusahaan (Customer Retention). Relationship Marketing pertama kalinya didefinisikan sebagai bentuk pengembangan aktivitas kampanye pemasaran yang menekankan kepuasan dan retensi pelanggan (Kotler \& Keller, 2009).

Relationship Marketing adalah konsep pemasaran yang sangat penting untuk menarik dan mempertahankan pelanggan suatu produk. Dalam dunia bisnis modern, fokus pemasaran mencerminkan pergerakan perubahan dari pemasaran transaksional ke Relationship Marketing. Membangun, memelihara dan selalu meningkatkan hubungan antara perusahaan dan pelanggan merupakan aspek penting dari bisnis. Konsep Relationship Marketing menjelaskan bahwa dalam meningkatkan hubungan yang kuat perusahaan dengan pelanggannya adalah dengan cara membuat pelanggannya yang semula acuh tidak acuh menjadi loyal. Relationship Marketing merupakan multidimensi yang terdiri dari enam komponen yakni kepercayaan, komitmen, komunikasi, persepsi nilai, sikap empati dan timbal balik.

Perguruan tinggi sebagai penyedia jasa layanan pendidikan, juga perlu untuk menawarkan solusi dan nilai tambah. Perguruan tinggi, khususnya PTS juga menerapkan teori Relationship Marketing dalam praktek mengelola hubungan antara perguruan tinggi dengan mahasiswanya. Konsep Relationship Marketing merupakan ujung tombak dari praktek pemasaran di bidang layanan akademik. Relationship Marketing Theory dapat diterapkan pada konteks pelayanan jasa di perguruan tinggi, karena perguruan tinggi juga merupakan organisasi pelayanan. Untuk itu, pendekatan Relationship Marketing juga diperlukan dalam pelayanan pemasaran jasa kepada mahasiswa variabel-variabel yang 
terdapat pada teori ini adalah kepercayaan, persepsi nilai, komunikasi dan loyalitas Variabel - variabel ini menjelaskan hubungan jangka panjang perusahaan dengan para pelanggannya (Henning \& Langer, 2001).

Adapun dimensi-dimensi yang terdapat Relationship Marketing adalah kepercayaan, komitmen, kepuasan, komunikasi, kekuasaan, persepsi nilai, ikatan, kerjasama, penyesuaian, manfaat hubungan switching cost, kompetensi, dan daya tarik alternatif. Dari ketiga belas dimensi tersebut, yang paling sering dikutip dalam literatur adalah kepercayaan, komitmen, kepuasan dan komunikasi.

Sementara tiga dimensi utama yang disepakati adalah kepercayaan, komitmen dan kepuasan. Hal ini didasarkan intisari dari 64 (enam puluh empat) artikel dari jurnal-jurnal pemasaran yang dikumpulkan dari tahun 1987 sampai dengan Maret 2007, untuk mengukur kualitas hubungan antara produsen dan konsumen.

Konsep Relationship Marketing sendirijuga terdapat dalam beberapa literatur komunikasi pemasaran. konsep Relationship Marketing mensyaratkan perusahaan untuk memiliki kompetensi dalam menjalin komunikasi tetap dengan pelanggan untuk memastikan tujuan tercapai, serta memadukan proses Relationship Marketing ke dalam rencana strategi sehingga memungkinkan perusahaan untuk mengelola sumber daya dengan baik dan memenuhi kebutuhan konsumen pada masa mendatang.

Konsep Relationship Marketing juga menjadi sumber dalam pengukuran hubungan antara produsen dan konsumen dalam perspektif Public Relations (Customer Relations). Ini dibuktikan yang mengevaluasi kualitas hubungan perusahaan dengan publiknya dalam makalah yang berjudul Guidelines for Measuring Relationships in Public Relations. Terutama pada aspek-aspek yang berkait dengan kepercayaan pelanggan, komitmen perusahaan, persepsi nilai dan kepuasan pelanggan (Hon \& Grunig, 1999).

Today, however, marketing theorists talk of Relationship Marketing and the idea that it is much cheaper to keep a customer that to attract a new one. Marketing theorists have used at least two of the relationship indicators identified in this paper - trust and commitment - to describe a good relationship with customers. Morgan and Hunt defined brand loyalty as commitment and as an executive of a major Public Relations firm has said that the value of a brand is nothing more than trust in a product (Hon \& Grunig, 1999).

Kesimpulannya adalah teori pertukaran sosial dan konsep Relationship Marketing memiliki pertalian erat. Teori pertukaran sosial menekankan hubungan antar individu yang memuaskan ditinjau dari segi ganjaran dan biaya. Sementara, Relationship Marketing menitikberatkan pada bagaimana perusahaan mampu memberikan layanan yang berkualitas 
sehingga pelanggan merasakan adanya keuntungan dalam hubungan tersebut.

Berikut ini adalah tiga model yang melibatkan kualitas hubungan dalam kaitannya dengan loyalitas mahasiswa.Pertama, model RSQL (Relationship Quality-based Students Loyalty) yang dikembangkan oleh HennigThurau yang menempatkan elemen penting Relationship Marketing dalam konteks pendidikan tinggi. Proposisi ini mendasari dimensi-dimensi kualitas hubungan (relationship quality) dalam penelitian ini untuk menentukan loyalitas mahasiswa (Henning \& Langer, 2001).

Selain itu, dimensi-dimensi yang tergabung dalam kualitas hubungan adalah kualitas layanan (terutama pengajaran dari guru/dosen) dan komitmen, yang terbagi menjadi tiga, yakni komitmen kognitif, komitmen emosional dan komitmen tujuan. Hasilnya, kualitas hubungan memiliki pengaruh positif terhadap peningkatan loyalitas mahasiswa.

Komitmen emosional dalam penelitian ini menjadi satu-satunya komitmen yang paling banyak dipengaruhi oleh banyak faktor dibandingkan komitmen kognitif dan komitmen tujuan. Komitmen emosional tersebut dipengaruhi oleh komitmen mahasiswa terhadap keluarganya, komitmen pekerjaan, komitmen terhadap aktivitas-aktivitas non perguruan tinggi, integrasi pada sistem sosial, dan integrasi pada sistem akademik.

Model penelitian pada gambar 1 membuktikan bahwa terdapat hubungan yang erat antara kualitas hubungan dalam konteks pendidikan yang dipersepsikan oleh mahasiswa dan loyalitas mahasiswa. Penelitian tersebut juga membuktikan bahwa komitmen emosional dan kepercayaan mahasiswa merupakan faktor penting yang menentukan loyalitas mahasiswa.

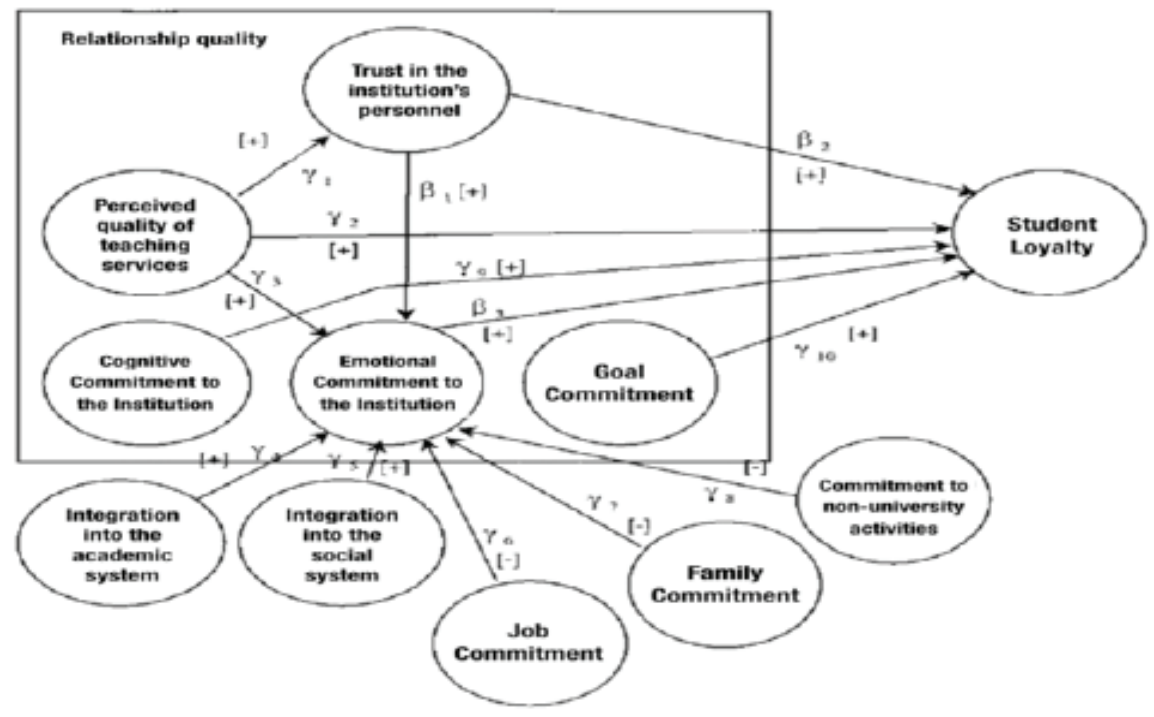

Sumber: Henning \& Langer, 2001

Gambar 1 Model Loyalitas Mahasiswa Berbasis Kualitas Hubungan 
Model selanjutnya yang disajikan dalam gambar 2 adalah model yang dikembangkan oleh Mendez et al yang menyatakan bahwa loyalitas mahasiswa jangka panjang merupakan elemen kunci kesuksesan perguruan tinggi tersebut ditinjau dari keuntungan yang kompetitif. Alasannya adalah bahwa dengan adanya loyalitas mahasiswa yang tinggi akan menghemat biaya untuk menjaring mahasiswa baru oleh karena adanya donasi (dari mahasiswa atau alumni) dan promosi komunikasi getok tular (word of mouth communication) yang dilakukan oleh mahasiswa yang loyal tersebut (Mendez, 2009).

Model Mendez ini menggambarkan mengenai pengaruh kualitas layanan terhadap loyalitas mahasiswa melalui kualitas hubungan jangka panjang yang meliputi dimensidimensi yakni persepsi kualitas/nilai, kepuasan mahasiswa, kepercayaan mahaiswa (Trust), dan komitmen (Commitment). Kontribusi dari model Mendez et al ini adalah menjelaskan secara lebih komprehensif mengenai dimensidimensi yang terdapat pada konstruk kualitas hubungan (jangka panjang) yang dibangun oleh mahasiswa dengan perguruan tinggi/kampusnya tersebut.

Terakhir adalah model yang dikembangkan oleh Brown dan Mazzarol mengenai pengaruh citra perguruan tinggi di Australia terhadap loyalitas pelanggan (mahasiswa) melalui persepsi nilai dan kepuasan mahasiswa. Model ini menjelaskan adanya pengaruh yang kuat dari kepuasan mahasiswa terhadap loyalitas

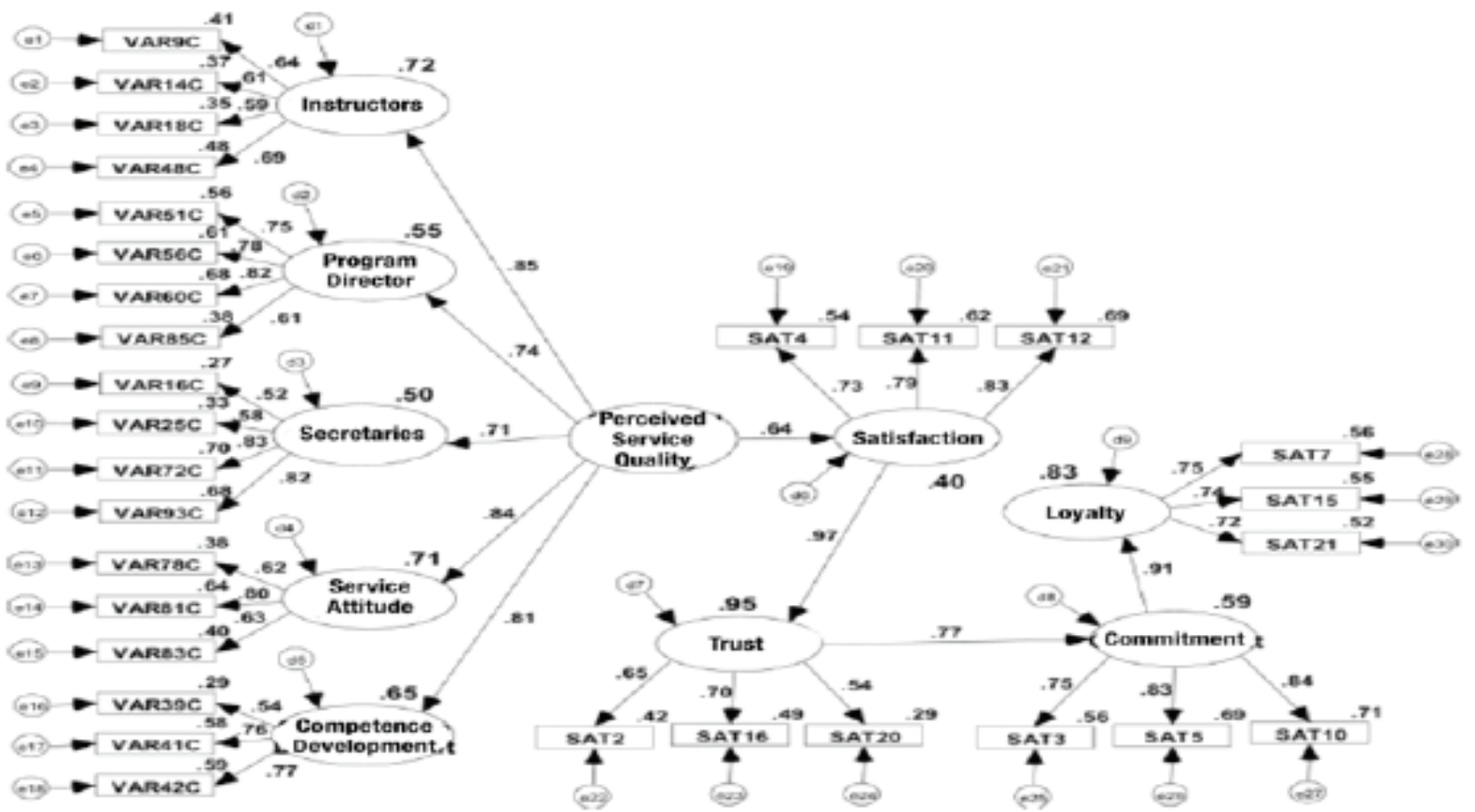

Sumber: Mendez, 2009

Gambar 2 Model Kualitas Layanan \& Kualitas Hubungan Jangka Panjang 


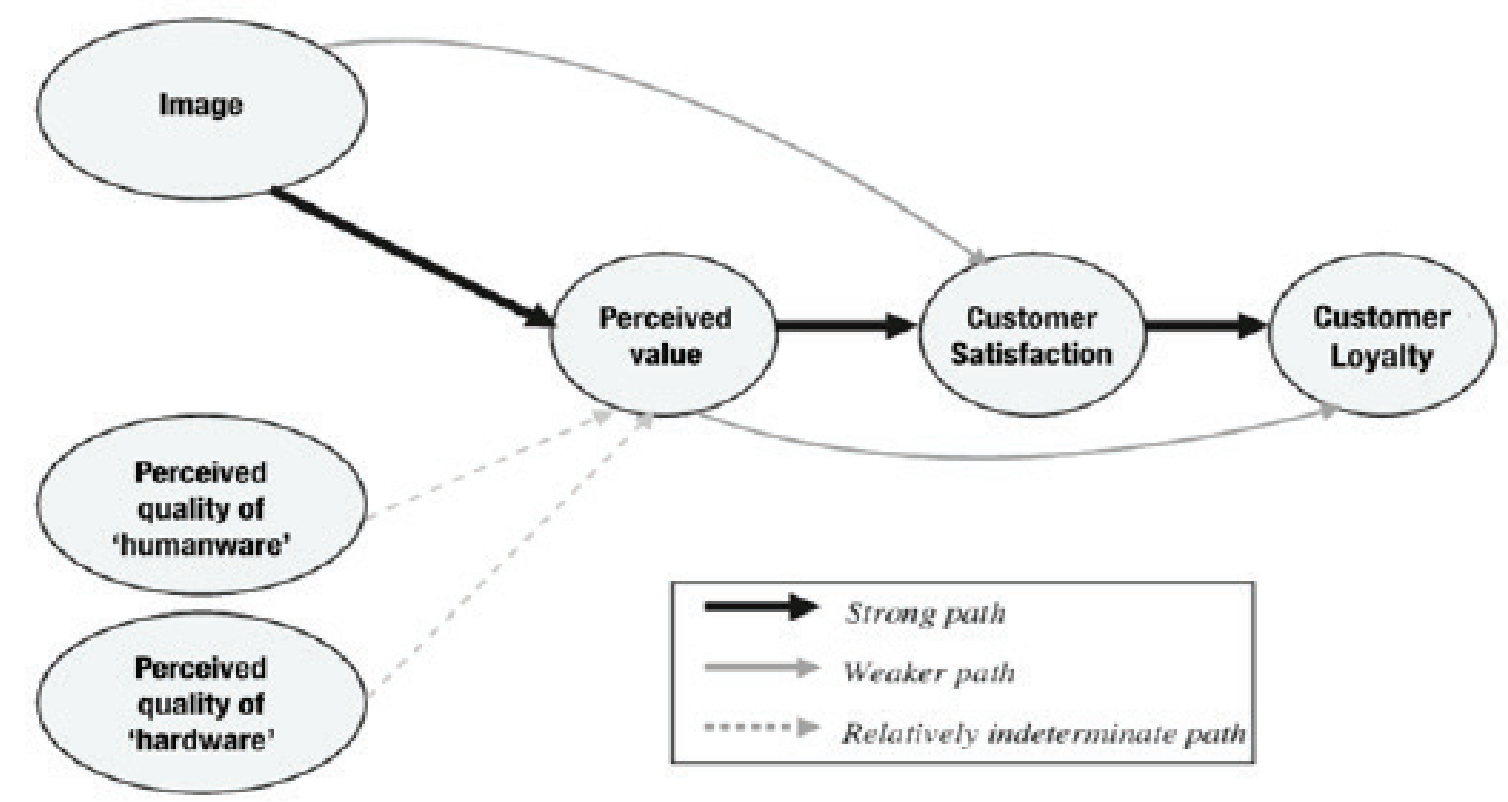

Sumber: Brown \& Mazzarol, 2009

\section{Gambar 3 Model Loyalitas Mahasiswa Berdasarkan Kepuasan, Persepsi Nilai dan Citra Perguruan Tinggi di Australia}

mahasiswa (Brown \& Mazzarol, 2009. Namun demikian, model ini tidak menjelaskan keterkaitan antara persepsi kualitas layanan dan citra terhadap loyalitas.

Model pada gambar 3 menjelaskan bahwa variabel citra merupakan variabel pengaruh yang penting yang menentukan/memengaruhi kepuasan mahasiswa dalam konteks perguruan tinggi diAustralia. Variabel citra perguruantinggi disini terdiri dari tiga dimensi yakni lingkungan studi, kepraktisan, dan kekonservatifan.

Lingkungan studi maksudnya adalah bagaimana lingkungan perguruan tinggi tersebut nyaman, ramah, suportif dan inovatif. Kepraktisan adalah fleksibel tidaknya pada saat mendaftar sebagai mahasiswa di perguruan tinggi tersebut ("practicality" whether the entry was flaxible or not). Sedangkan kekonservatifan merupakan ukuran dimana perguruan tinggi tersebut memiliki atau tidaknya reputasi atau prestis yang baik sepanjang sejarah berdirinya. Model tersebut juga menyatakan adalanya "Perceived Value" atau persepsi nilai yang merupakan variabel antara yang menghubungkan citra perguruan tinggi dengan kepuasan mahasiswa dan loyalitas mahasiswa.

Singkatnya, model Brown dan Mazzarol menambahkan adanya citra perguruan tinggi sebagai variabel bebas yang cukup esensial di samping kualitas layanan walaupun tidak memiliki pengaruh langsung terhadap loyalitas mahasiswa (Brown \& Mazzarol, 2009). Kemudian, variabel persepsi nilai dan kepuasan mahasiswa sebagai variabel antara yang memengaruhi variabel loyalitas mahasiswa. Menurutnya selama masih terdapat kompetisi 
yang intens antar perguruan tinggi di dunia, maka membangun brand dan meningkatkan citra perguruan tinggi adalah sesuatu hal yang krusial yang harus dilakukan.

Selain itu, menulis makalah yang cukup terkenal yang berjudul "Guidelines for Measuring Relationship in Public Relations". Mereka mengidentifikasi empat hasil akhir dari kualitas hubungan jangka panjang yang positif yang berkaitan dengan langkah awal dalam melakukan audit hubungan publik dengan organisasi. Keempat hasil akhir tersebut adalah; 1). Mutualitas Pengendalian: derajat persetujuan kedua belah pihak mengenai siapa yang memiliki Kendali untuk memengaruhi satu sama lain. 2). Kepercayaan: level kepercayaan dari salah satu pihak dalam keinginan untuk membuka diri terhadap pihak yang lain. 3). Kepuasan: sejauh mana dari salah satu pihak merasa puas dan nyaman terhadap yang lain karena ekspektasi positif mengenai hubungan yang diteguhkan. 4). Komitmen: sejauhmana salah satu pihak memiliki kepercayaan dan merasa bahwa hubungan akan lebih bermakna dengan energi yang telah digunakan untuk mempertahankan dan meningkatkan hubungan tersebut (Hon \& Grunig, 1999).

Keempat hasil akhir dari Hon dan Grunig menjadi basis dimensi-dimensi kualitas hubungan pada model loyalitas mahasiswa Khusus untuk dimensi. Mutualitas pengendalian sangat berkait dengan energi, biaya dan waktu yang dikeluarkan, maka dalam penelitian ini dianalogikan sebagai dimensi persepsi nilai. Berikut ini adalah penejelasan secara detail mengenai keempat dimensi tersebut yakni kepercayaan mahasiswa pada perguruan tinggi, komitmen studi, persepsi nilai dan kepuasan mahasiswa (Taecharungroj, 2013).

Pertama adalah kepercayaan mahasiswa pada perguruan tinggi. Dalam konteks perguruan tinggi, kepercayaan didefinisikan sebagai derajat dimana seorang mahasiswa memiliki keyakinan pada kampusnya, bahwa perguruan tinggi tersebut memberikan benefit baginya dalam proses belajar yang dilakukannya dan dalam mencapai tujuan kesuksesan karirnya (Ghosh, Whipple, \& Bryan, 2001).

Kepercayaan mahasiswa berdasarkan pengalaman pribadi dari setiap mahasiswa dengan anggota-anggota organisasi perguruan tinggi (Faculty Members). Kepercayaan mahasiswa dibangun dari integritas, kompetensi, konsistensi/keterandalan dan keterbukaan (Henning \& Langer, 2001).

Dengan demikian, indikator-indikator yang digunakan didalam penelitian ini mengikuti indikator-indikator dari penelitian-penelitian sebelumnya yakni integritas yang diukur dari karakter personal dan dorongan untuk maju, kemudian kompetensi yang diukur dari perilaku kerja yang baik dan kemampuan berkomunikasi 
personal yang baik. Dua indikator yang lain yakni keterandalan yang diukur dari seberapa tepat perguruan tinggi untuk menepati janjinya pada mahasiswa, memprioritaskan minat pelanggan dan kemampuan mengevaluasi serta kemampuan untuk membuka diri (Leonard \& Sukandar, 2014).

Kedua adalah komitmen mahasiswa pada perguruan tinggi. Komitmen sebagai kepercayaan seseorang terhadap hubungan yang sedang berjalan merupakan sesuatu hal yang sangat penting, yang menjamin usaha yang maksimal untuk mempertahankannya. Pihak yang berkomitmen mempercayai bahwa hubungan adalah usaha bernilai untuk memastikan sesuatu yang tidak pasti. Komitmen umumnya diketagorisasikan sebagai usaha keberlanjutan, sesuatu yang kalkulatif.

Komitmen yang berkelanjutan terjadi ketika seseorang merasa terikat pada suatu entitas. Dengan demikian, dapat dikatakan bahwa seseorang yang memiliki komitmen pada suatu lembaga, maka dia akan melanjutkan hubungan karena benefit yang diperoleh dari hubungan tersebut. Komitmen diukur dari kepemilikan identifikasi, rasa saling memiliki, kesukaan, keterlibatan, kepercayaan, berbagi nilai, dan kesamaan personal (Moore \& Bowden, 2012).

Dengan demikian, indikator-indikator yang digunakan pada dimensi komitmen studi dalam penelitian ini adalah identifikasi diri, rasa saling memiliki, dan rasa suka pada kampusnya. Indikator yang lain diadopsi dari (Henning \& Langer, 2001) yakni keterlibatan dalam aktivitas-aktivitas di kampus, kepedulian terhadap kampus dan pengabdian maksimal untuk lembaga.

Ketiga adalah persepsi nilai. Nilai atau persepsi nilai merupakan salah satu konstruk kualitas hubungan yang dipelajari dalam penelitian ini. Peran dari biaya, energi dan waktu yang dikeluarkan pada saat menjalani studi merupakan hal-hal yang dipertimbangkan dalam konsep ini Persepsi nilai adalah kemampuan kognitif yang menjelaskan persepsi kualitas ditinjau dari pengorbanan atas segala sumber daya yang telah dikeluarkan (Taecharungroj, 2013).

Dalam konteks perguruan tinggi, biaya, waktu dan energi adalah sumber daya yang fundamental yang dimiliki oleh mahasiswa untuk mendapatkan layanan pendidikan yang maksimal dan memuaskan. Dengan demikian, indikator-indikator yang digunakan dalam dimensi persepsi nilai ini adalah waktu studi, biaya pendidikan dan energi yang sudah dikeluarkan selama studi (Clemes, Gan, \& Kao, 2007).

Terakhir adalah kepuasan mahasiswa sebagai pelanggan. Kepuasan pelanggan telah banyak diperdebatkan dalam berbagai literatur, baik itu dalam ilmu bisnis maupun manajemen. 
Namun demikian, tidak ada satu kesepakatan mengenai definisi konsep kepuasan dengan layanan, khususnya di pendidikan tinggi.

Mereka mendefinisikan kepuasan mahasiswa adalah adalah sikap jangka pendek yang dihasilkan dari evaluasi pengalaman mereka dari layanan pendidikan yang diterima. Kepuasan mahasiswa disini berarti evaluasi pengalaman mereka terhadap pengalaman mereka berinteraksi tidak hanya dengan dosen dan staf, namun juga informasi-informasi yang mereka butuhkan dan sarana fasilitas yang digunakan untuk menunjang proses belajarmengajar mereka.

Kotler \& Keller mendefinisikan kepuasan (satisfaction) sebagai perasaan senang atau kecewa seseorang yang timbul karena membandingkan kinerja yang telah dipersepsikan produk (atau hasil) terhadap ekspektasi mereka (Kotler \& Keller, 2009). Jika kinerja gagal memenuhi ekspektasi, pelanggan akan tidak puas. Jika kinerja sesuai dengan ekspektasi, maka pelanggan akan puas. Jika kinerja melebihi ekspektasi, maka pelanggan akan sangat puas.

Definisi kepuasan mahasiswa dalam konteks akademik dapat dilihat dari sebelas indikator/faktor yakni sebagai berikut; layanan konsultasi/advis, kualitas pengajaran, ketersediaan mata kuliah yang dianggap memberikan keahlian, materi perkuliahan, keberagaman mata kuliah yang ditawarkan di dalam satu program studi, pengalaman selama studi secara keseluruhan, kesesuaian program studi dengan tujuan, pemberian nilai (grading), layanan bimbingan karir atau konsultasi untuk studi lanjut, ketersediaan mata kuliah pilihan yang beragam dan ukuran kelas di program studi yang ditempuh (Tessema, Ready, \& Yu, 2012).

Indikator-indikator yang digunakan dalam dimensi kepuasan mahasiswa mengadopsi evaluasi terhadap fasilitas-fasilitas yang ada di kampus (Hon \& Grunig, 1999). Adapun indikator-indikator yang terdapat pada masingmasing dimensi dalam kualitas hubungan, sebagaimana yang terdapat pada variabel kualitas layanan dan citra perguruan tinggi yang telah disebut sebelumnya, adalah mengadopsi dari beberapa penelitian-penelitian sebelumnya. Misalnya dimensi kepercayaan dari mahasiswa yang terdiri dari indikatorindikator integritas yang diterapkan pada hubungan antara perguruan tinggi (terutama dari dosen dan staf administrasi) dengan mahasiswa-mahasiswinya. Begitu pula pada dimensi komitmen, kepercayaan dan kepuasaan mahasiswa sebagai pelanggan terhadap perguruan tinggi yang mengadopsi indikator pada penelitian-penelitian sebelumnya (Leonard \& Sukandar, 2014).

Variabel kualitas hubungan terdiri dari 
empat dimensi yang meliputi kepercayaan dari mahasiswa (trust), komitmen studi (commitment), persepsi nilai (perceived value), dan kepuasan mahasiswa. Kepercayaan mahasiswa meliputi tiga indikator yang meliputi integritas, konstitensi, dan keterbukaan (Leonard \& Sukandar, 2014). Integritas dapat diukur dari seberapa positif yang dimiliki dosen dan sejauh mana karyawan dapat dipercaya.

Konsistensi dapat diukur dari seberapa sesuai janji dosen yang diberikan terhadap mahasiswa. Keterbukaan dapat diukur dari seberapa besar kemampuan membuka diri dosen terhadap mahasiswanya. Komitmen studi meliputi empat indikator yakni identifikasi diri, saling memiliki, keterlibatan, dan berbagi nilai. Dimensi ini diadopsi dari (Henning \& Langer, 2001). Identifikasi diri dapat diukur dari seberapa bangga mahasiswa menggunakan atribut institut. Saling memiliki dapat diukur melalui seberapa besar rasa keterikatan mahasiswa terhadap institut.

Keterlibatan dapat diukur dari seberapa besar mahasiswa berperan aktif dengan kegiatan institus. Berbagi nilai dapat diukur melalui seberapa besar mahasiswa memberi bantuan terhadap institut. Persepsi nilai meliputi tiga indikator yakni waktu studi, biaya pendidikan, dan energi belajar. Waktu studi dapat diukur dari persepsi mahasiswa terhadap waktu yang digunakan untuk studi. Biaya pendidikan dapat diukur dari persepsi mahasiswa terhadap biaya yang dihabiskan untuk studi. Energi belajar dapat diukur dari persepsi mahasiswa terhadap usaha dan tenaga untuk menyelesaikan studi (Carvalho \& Mo, 2010).

Kepuasan mahasiswa meliputi tiga indikator yakni kepuasan komunikasi/emosi pada informasi, evaluasi fasilitas, dan kepuasan terlibat dalam aktivitas kampus. Kepuasan komunikasi/emosi pada informasi dapat diukur dari seberapa puas mahasiswa berkomunikasi tatap muka dengan dosen dan seberapa puas mahasiswa terhadap proses komunikasi menggunakan media dengan dosen. Kepuasan komunikasi pada informasi juga diukur dari seberapa puas mahasiswa berkomunikasi dengan staf, seberapa puas mahasiswa pada informasi pembayaran kuliah, seberapa puas mahasiswa pada pemberitaan mengenai institut, dan seberapa puas mahasiswa pada materi kuliah dan kurikulum.

Evaluasi fasilitas dapat diukur dari seberapa puas mahasiswa pada kantin, lapangan parkir, ruang kemahasiswaan, lapangan olahraga, dan fasilitas lainya di kampus, seberapa puas mahasiswa pada wifi kampus. Evaluasi fasilitas juga dapat diukur dari seberapa puas mahasiswa pada kebersihan ruang dan gedung, dan seberapa puas mahasiswa pada kelengkapan buku. Kepuasan terlibat dalam aktivitas kampus dapat diukur dari seberapa puas mahasiswa 
Tabel 1 Operasionalisasi Variabel Kualitas Hubungan

\begin{tabular}{|c|c|c|}
\hline Dimensi & Indikator & Pengukuran \\
\hline \multirow{4}{*}{$\begin{array}{l}\text { Kepercayaan dari } \\
\text { Mahasiswa (Trust) }\end{array}$} & Integritas (Carvalho \& Mota; 2010) & Sifat positif yang dimiliki dosen \\
\hline & & Staf karyawan dapat dipercaya \\
\hline & Konsistensi (Leonnard et al, 2014) & Sesuai dengan apa yang dijanjikan \\
\hline & Keterbukaan (Leonnard et al, 2014) & Kemampuan membuka diri \\
\hline \multirow{4}{*}{$\begin{array}{l}\text { Komitmen Studi } \\
\text { (Commitment) }\end{array}$} & Identifikasi diri (Fullerton, 2003) & Bangga menggunakan atribut Institut \\
\hline & Saling memiliki (Fullerton, 2003) & Rasa keterikatan institut \\
\hline & $\begin{array}{l}\text { Keterlibatan (Henig Thurau et.al } \\
\text { 2002) }\end{array}$ & Berperan aktif kegiatan institut \\
\hline & $\begin{array}{l}\text { Berbagi nilai (Henig Thurau et.al } \\
\text { 2002) }\end{array}$ & Memberi bantuan \\
\hline \multirow{3}{*}{$\begin{array}{l}\text { Persepsi Nilai (Per- } \\
\text { ceived Value) }\end{array}$} & Waktu studi (Ostergaard et.al, 2005) & Waktu yang digunakan untuk studi \\
\hline & $\begin{array}{l}\text { Biaya pendidikan (Clemens et.al, } \\
\text { 2007) }\end{array}$ & Biaya yang dihabiskan untuk studi \\
\hline & $\begin{array}{l}\text { Energi belajar (Carvalho \& Mot- } \\
\text { ta,2010) }\end{array}$ & $\begin{array}{l}\text { Usaha untuk menyelesaikan studi } \\
\text { Tenaga demi terselesaikannya studi }\end{array}$ \\
\hline \multirow[t]{11}{*}{$\begin{array}{l}\text { Kepuasan } \\
\text { siswa }\end{array}$} & $\begin{array}{l}\text { Kepuasan Komunikasi/Emosi pada } \\
\text { Informasi (Helgesen \& Nesset, 2007b) }\end{array}$ & $\begin{array}{l}\text { Puas terhadap proses komunikasi tat- } \\
\text { ap muka dengan dosen }\end{array}$ \\
\hline & & $\begin{array}{l}\text { Puas terhadap proses komunikasi } \\
\text { bermedia dengan dosen }\end{array}$ \\
\hline & & Puas berkomunikasi dengan staf \\
\hline & & Puas pada informasi pembayaran \\
\hline & & Puas pada pemberitaan institut \\
\hline & & Puas pada materi kuliah \& kurikulum \\
\hline & Evaluasi Fasilitas (Egyir, 2015) & $\begin{array}{l}\text { Puas pada kantin, lapangan parkir, } \\
\text { ruang kemahasiswaan, lapangan } \\
\text { olahraga dan fasilitas lain di kampus }\end{array}$ \\
\hline & & Puas dengan wifi \\
\hline & & $\begin{array}{l}\text { Puas pada kebersihan ruang dan ge- } \\
\text { dung }\end{array}$ \\
\hline & & Puas pada kelengkapan buku \\
\hline & & $\begin{array}{l}\text { Puas pada informasi aktivitas-aktivi- } \\
\text { tas yang diselenggarakan Institut }\end{array}$ \\
\hline
\end{tabular}

Sumber: Taecharungroj, 2013

pada informasi aktivitas-aktivitas yang SIMPULAN

diselenggarakan institut. Adapun ringkasan dari operasionalisasi variabel kualitas hubungan dirangkum dalam matriks yang tersaji pada tabel 1 .

Penelitian-penelitian sebelumnya yang berkaitan dengan pembahasan hubungan mahasiswa dan perguruan tinggi dalam konteks komunikasi pemasaran dan Public Relations, 
sering mengabaikan konsep dari pengembangan hubungan. Penelitian yang terdahulu biasanya hanya membahas mengenai bagaimana pengaruh citra terhadap kepuasan mahasiswa atau hubungan antara kualitas layanan dan kepuasan serta loyalitas.

Padahal, faktor pengembangan hubungan merupakan aspek yang cukup penting dalam menentukan seberapa tinggi loyalitas mahasiswa terhadap perguruan tingginya. Melalui konsep Customer Relations dalam kajian Public Relations, diharapkan penelitian-penelitian berikut yang membahas mengenai kepuasan dan loyalitas mahasiswa, dapat memperhatikan dan melibatkan model Kualitas Hubungan, yang memang banyak diadopsi dari pedoman pengukuran evaluasi hubungan perusahaan dan publiknya.

\section{DAFTAR PUSTAKA}

Alma, B. (2005). Manajemen pemasaran dan pemasaran jasa. Bandung: Alfabeta.

Ardianto, E. (2014). Metodologi penelitian untuk public relation: kuantitatif dan kualitatif. Bandung: Remaja Rosdakarya.

Blau, P. (1964). Exchange \& power in social life.

Brown, R. M. \& Mazzarol, T. (2009). The importance of institutional image to student satisfaction and loyalty within higher education. Higher Education, 58, 17-35.

Carvalho, S. W. \& Mo, M. (2010). The role of trust in creating value and student loyalty in relational exchanges between higher education institutions \& their students. Journal of Marketing for Higher Education, 20(1).

Clemes, M. D., Gan, C. E. C., \& Kao, T. H. (2007). University student satisfaction: an empirical analysis. Journal of Marketing for Higher Education, 17(2), 27-38.

Ghosh, A. K., Whipple, T. W., \& Bryan, G. A. (2001). Student trust and its antecedents in higher education. The Journal of Higher Education, 72(3), 322-340.

Henning, T. \& Langer, H. M. (2001). Modelling and managing student loyalty an approach base dont he concept of relationship quality. Journal of Service Research, 3(4), 331-334.

Hon, L. C. \& Grunig, J. E. (1999). Guidelines for measuring relationships in public relations. United States of America: Institut Public Relations.

Kara. (2004). Business student satisfaction, intentions and retention in higher education. Pennsylvania State University, Vol 3.

Kotler, P. \& Keller, K. L. (2009). Manajemen pemasaran. Jakarta: Erlangga.

Kriyantono, R. (2014). Teknik praktis riset komunikasi. Jakarta: Kencana Prenada Media Group.

Leonard, H. D. \& Sukandar, Y. D. (2014). The loyalty model of private university students. International Research Journal of Business Studies, 7(1), 40-51.

Mendez, J. R. (2009). Determinants of student loyalty in higher education: a tested relationship approach in latin america, 10, 21-39.

Moore, D. \& Bowden, J. L. (2012). An appealing connection - the role of relationship marketing in the attraction and retention of students in an australian tertiary context. 
Asian Social Science, 8(4), 65-80.

Rakhmat, J. (2007). Metode penelitian komunikasi: dilengkapi dengan contoh analistik statistik. Bandung: Remaja Rosdakarya.

Ramist, L. (1981). College student attrition and retention college board report. College Entrance Examination Board, 1(S1).

Syam, N. (2011). Psikologi: sebagai akar ilmu komunikasi, seri pohon komunikasi. Bandung: Simbiosa Rekatama Media.

Taecharungroj. (2013). University student loyalty model: structural equation modelling of student loyalty in autonomous, state, transformed, west and private universities in bangkok. National Institute of Development Administration, 10(1), 2240.

Tessema, M., Ready, K., \& Yu, W.(2012). Factors affecting college students satisfaction with major curriculum: evidence from nine years of data. International Journal of Humanities and Social Science, 2(2), 5065.

Tobari. (2015). Strategi perguruan tinggi swasta menghadapi persaingan. Jurnal Media Wahana Ekonomika, Vol 12 No.

West, R. \& Turner. (2009). Pengantar teori komunikasi: analisis dan aplikasi. Jakarta: Salemba Humanika. 